\title{
Dzieło sztuki jako źródło wiedzy w badaniach geograficznych
}

\author{
Work of art as a source in geographical research
}

\begin{abstract}
JERZY BAŃSKI
Instytut Geografii i Przestrzennego Zagospodarowania im. S. Leszczyckiego PAN, 00-818 Warszawa, ul. Twarda 51/55; jbanski@twarda.pan.pl
\end{abstract}

\begin{abstract}
Zarys treści. Celem rozważań jest ocena możliwości wykorzystania klasycznego dzieła sztuki jako źródła wiedzy w badaniach geograficznych oraz charakterystyka modelu przekazu informacji od twórcy do odbiorcy dzieła. Dzieło sztuki może być źródłem wiedzy w badaniach geograficznych, musi jednakże spełniać kilka podstawowych warunków. Spośród różnych rodzajów dzieł sztuki, szczególną rolę w badaniach geograficznych mogą odgrywać dzieła plastyczne (głównie malarstwo), literatura piękna oraz film. Mają one na ogół charakter dokumentacyjny, tj. przedstawiają fragment przestrzeni geograficznej w przeszłości historycznej.
\end{abstract}

Słowa kluczowe: sztuka, geografia, źródło wiedzy, geografia sztuki.

\section{Wstęp}

Sztuka jest dziedziną działalności człowieka o bardzo szerokim spektrum przedmiotowym i tematycznym. Dlatego trudno ją zdefiniować; nie ma jednej ogólnie akceptowanej definicji, lecz wiele prób definiowania, które z biegiem czasu i powstawaniem nowych dziedzin sztuki muszą być modyfikowane. Równie trudno więc o definicję „dzieła sztuki”, a sprawę komplikuje jeszcze występowanie w teorii kultury pojęcia „przedmiot artystyczny”, którego konotacja ma cechy wspólne z tym pierwszym. Pozostawiając problemy definicyjne bardziej kompetentnym badaczom przyjmijmy, że w naszych rozważaniach dzieło sztuki będzie rozumiane w sposób potoczny - jako „wytwór estetyczny” człowieka uprawiającego sztukę. Takim wytworem jest na przykład dzieło plastyczne, utwór literacki, dzieło muzyczne, sztuka teatralna, itp.

Nauka i sztuka, to dwa różne sposoby poznawania, opisu i rozumienia świata. Nauka dąży do obiektywizmu oraz wyjaśnienia praw i zasad funkcjonowania świata, sztuka - to subiektywizm i interpretacja rzeczywistości. Sztuka i jej wytwory są przedmiotem badań wielu dyscyplin naukowych, ale i w zakre- 
sie sztuki jako takiej nadawane są stopnie i tytuły naukowe (sztuki: teatralne, muzyczne, filmowe i plastyczne). Wynika z tego, że granica pomiędzy nauką i sztuką jest płynna, dlatego niektóre „fragmenty” nauk humanistycznych traktowane są również jako sztuka (antropologia literatury, etnologia, estetyka). Szczególne miejsce na pograniczu sztuki i nauki zajmuje architektura, wymagająca od swych przedstawicieli wiedzy i umiejętności artystycznych oraz wiedzy inżynierskiej. Takich dylematów nie ma geografia, mocno ugruntowana wśród nauk realnych. Jednakże warto zastanowić się, jakie relacje występują pomiędzy geografią i sztuką. Celem artykułu jest ocena możliwości wykorzystania klasycznego dzieła sztuki, na przykładzie literatury pięknej i malarstwa, jako źródła nowej wiedzy w badaniach geograficznych oraz omówienie modelu przekazu informacji geograficznej za pomocą dzieła sztuki.

\section{Sztuka w badaniach geograficznych}

Sztuka sama w sobie bywa przedmiotem badań geograficznych. Interesują się nią przede wszystkim geografowie kultury. Ich badania koncentrują się na analizie zróżnicowania przestrzennego form sztuki, w tym głównie malarstwa, muzyki i filmu (Brouillette i Feler, 2010; Carney, 1998; Lukinbeal, 2005; Kaufmann, 2004; Nash, 1968; Lorneta i Valdes, 2007) lub identyfikacji specyficznych elementów sztuki (często tradycyjnej sztuki ludowej) w ujęciu lokalnym lub regionalnym (Berry, 1988; Fiona i Mackenzie, 2006; Morris, 2005; Karan, 1984). Na przykład T. Kaufmann (2004) w swoim podręczniku analizuje wykorzystanie idei geograficznych w teorii historii sztuki. Autor stara się m.in. wykazać, że niektóre koncepcje historii sztuki są wyraźnie związane z lokalizacją miejsc tworzenia dzieł artystycznych. W innym miejscu rozważa możliwość przestrzennej dyfuzji nurtów artystycznych, dając przykład rozwoju nowych kierunków sztuki renesansowej w Europie Środkowej zapoczątkowanej przez włoskich rzeźbiarzy. Z kolei P. Karan (1984) ilustruje, jak lokalne pieśni i malarstwo pozwalają lepiej zrozumieć życie, kulturę i mentalność mieszkańców indyjskiego regionu Mithila.

Sztuka jest także edukacyjną metodą poznania geografii, wykorzystywaną przede wszystkim w Stanach Zjednoczonych (Jeffus i Aramini, 2008). Poprzez różne techniki sztuki malarskiej, graficznej, rysunkowej, uczniowie rozwijają wiedzę o świecie, zróżnicowaniu przyrodniczym, etnicznym itp.

Relacje pomiędzy geografią i sztuką mogą dotyczyć z jednej strony wiedzy o środowisku geograficznym wykorzystywanej przez artystę do tworzenia dzieła artystycznego, z drugiej zaś - wiedzy geograficznej płynącej z dzieła sztuki. Innymi słowy na sztukę można spojrzeć poprzez pryzmat wiedzy geograficznej, którą wykorzystuje artysta, ale także wiedzy o środowisku płynącej z jego twórczości. Taki nurt reprezentują na przykład D. Crouch i M. Toogood (1999), analizujący treści geograficzne zawarte w nowoczesnej 
sztuce abstrakcyjnej Petera Lanyona lub H. Hawkins (2010), badającej artystyczne rozumienie przestrzeni miejskiej w fotografiach i instalacjach Richarda Wentwortha. Podobny charakter mają prace I. Childs (1991), K. Olwig (1987) czy J. Seemann (2009).

W Polsce nieśmiałe próby podejmowania problematyki relacji 'geografiasztuka' pojawiają się przy okazji badań krajobrazu kulturowego (np. Orłowska, 2002). Jednakże można przyjąć, że geografia sztuki należy raczej do niszowych dziedzin w badaniach geograficznych w naszym kraju. Trzeba wyraźnie podkreślić, że niniejszy artykuł odbiega od głównego nurtu geografii kultury, bo odnosi się do sztuki nie jako przedmiotu badań, lecz jako źródła informacji i wiedzy w badaniach geograficznych.

Wśród wielu funkcji sztuki - estetycznej, etycznej, emocjonalnej, użytkowej, metafizycznej - jest też funkcja poznawcza, dzięki której odbiorca niektórych dzieł artystycznych może dowiedzieć się czegoś o teraźniejszej bądź przeszłej „rzeczywistości”. Trudno jednak tego oczekiwać od wszystkich dziedzin sztuki lub wytworów sztuki o charakterze abstrakcyjnym czy science fiction.

Sztuka jako źródło wiedzy naukowej jest tematem peryferyjnym i rzadko podejmowanym w rozważaniach naukowych. Najwięcej uwagi poświęcają temu zagadnieniu historycy, co wydaje się w pełni uzasadnione (Maternicki, 1963; Holzer, 1978; Topolski, 1978). Literatura, malarstwo lub rzeźba mogą bowiem stanowić istotne źródło informacji o czasach minionych, ówczesnej kulturze i tradycji, strukturze społecznej i szeregu innych zagadnień, którymi interesują się historycy. Jednakże jak zauważa A. Radomski (2001, s. 86): „Problem wykorzystania literatury pięknej jako źródła do badania przeszłości zawsze wzbudzał szereg kontrowersji (...) od totalnej negacji do „umiarkowanego" optymizmu...". Skoro sami historycy mają wątpliwości co do wartości dzieł sztuki (w tym przypadku literatury pięknej) jako źródeł informacji, trudno oczekiwać, aby problem ten był podejmowany przez geografów, którzy świat postrzegają zdecydowanie bardziej „materialnie”. Szczególnie badacze o nastawieniu scjentystycznym mogą być oburzeni próbami poszukiwania wiedzy geograficznej w wytworach artystycznych. Ale przecież i oni korzystają z opracowań kartograficznych, w których jest wyraźna „domieszka” sztuki. Kartograf interpretując rzeczywistość operuje miedzy innymi barwą i symbolem, które są elementem przekazu kartograficznego w postaci dwuwymiarowego dzieła - mapy.

Czy dzieło sztuki może być źródłem wiedzy w badaniach geograficznych? Intuicyjną odpowiedzią będzie „tak”, bo jesteśmy w stanie wskazać dzieła, które niosą ze sobą elementy informacji o środowisku geograficznym. Niezbędne wydaje się jednak zbadanie modelu przekazu informacji przez dzieło sztuki i wskazanie warunków, które musi ono spełnić, aby przekaz ten był przydatny geografowi, a więc miał charakter obiektywnej i rzetelnej informacji. 


\section{Model odbioru dzieła sztuki}

Dzieło sztuki można traktować przedmiotowo, jako medium przekazu informacji od twórcy do odbiorcy. Twórca dokonuje na ogół własnej (subiektywnej) interpretacji rzeczywistości, którą koduje w dziele artystycznym, natomiast odbiorca po rozkodowaniu sygnału twórcy tworzy nową - też subiektywną rzeczywistość. Jednakże podstawowym celem twórców posługujących się na przykład piórem lub pędzlem (słowem lub obrazem) jest wywołanie u odbiorcy ich „przedmiotu artystycznego” tzw. przeżycia estetycznego. Prowadzi ono do ukonstytuowania się estetycznego przedmiotu, „którego nie można utożsamiać z niczym rzeczywistym, czego spostrzeżenie daje impuls do rozwinięcia się przeżycia estetycznego i co zazwyczaj, zwłaszcza jeżeli jest w tym celu stworzonym dziełem sztuki, odgrywa rolę regulatora przebiegu tego przeżycia" (Ingarden, 1970, s. 97). Przeżycie estetyczne może towarzyszyć również badaczowi, który wykorzystuje dzieło sztuki do celów naukowych, ale nie stanowi ono żadnej $\mathrm{z}$ faz $\mathrm{w}$ procesie poszukiwania nowych informacji lub potwierdzenia wcześniej uzyskanych wniosków. Można nawet twierdzić, że przeżycie estetyczne, będące chwilowym usunięciem ze świadomości otaczającego nas świata i spraw zaprzątających umysł, jest doznaniem niewłaściwym w procesie wykorzystania dzieła jako źródła wiedzy naukowej. Postępowanie badacza powinno być bowiem obiektywne, logiczne i pozbawione cech metafizycznych (duchowych).

Przekaz informacji za pomocą dzieła sztuki ma cztery podstawowe fazy (ryc. 1):

1) odbiór realnego świata przez twórcę dzieła i jego interpretacja,

2) zakodowanie rzeczywistości w postaci dzieła artystycznego,

3) rozkodowanie przez odbiorcę sygnału płynącego z dzieła,

4) tworzenie przez odbiorcę rzeczywistości na podstawie dzieła.

W pierwszej fazie źródłem informacji jest świat realny postrzegany przez zmysły twórcy i interpretowany w jego umyśle. Twórca w procesie interpretacji rzeczywistości tworzy jej subiektywne wyobrażenie, dokonując selekcji i wyboru elementów świata realnego. Część elementów tego świata jest przez niego świadomie odrzucona lub pominięta przez „niedoskonałe” zmysły. Drugą fazą przekazu informacji jest zakodowanie interpretowanej rzeczywistości na komunikat dla przyszłych odbiorców za pomocą wybranych technik artystycznych w postaci dzieła sztuki. Może to być obraz, tekst literacki, grafika, miedzioryt, itp. Każde z nich jest zbiorem znaków o określonej desygnacji i konotacji. Procesowi temu towarzyszy również ubytek pewnych informacji o rzeczywistości. W trzeciej fazie komunikat twórcy jest odbierany i rozkodowywany przez zmysły odbiorcy. Również w tej fazie pewne elementy komunikatu ulegają odrzuceniu lub zanikowi. Na koniec odbiorca interpretuje komunikat przekazywany przez dzieło artystyczne i tworzy subiektywną rzeczywistość. Model można uszczegółowić wyodrębniając subfazy. 
W przekazie informacji za pośrednictwem dzieła artystycznego istotne jest to, czy subiektywny świat odbiorcy wykształcony na podstawie twórczego przekazu informacji artysty ma coś wspólnego ze światem realnym. Trudno oczekiwać sytuacji idealnej, aby świat ukształtowany u odbiorcy na podstawie wytworu artystycznego był w pełni zgodny ze światem realnym. Na skutek niedoskonałości zmysłów i pełnej swobody interpretacyjnej oraz twórczej, w każdej fazie przekazu informacji następuje utrata jej fragmentów. Jeżeli świat realny i świat subiektywny będą miały wspólną część, wówczas można przyjąć, że dzieło sztuki niesie jakieś wartości poznawcze; w przeciwnym wypadku jego wykorzystanie jako źródła informacji naukowej będzie niecelowe.

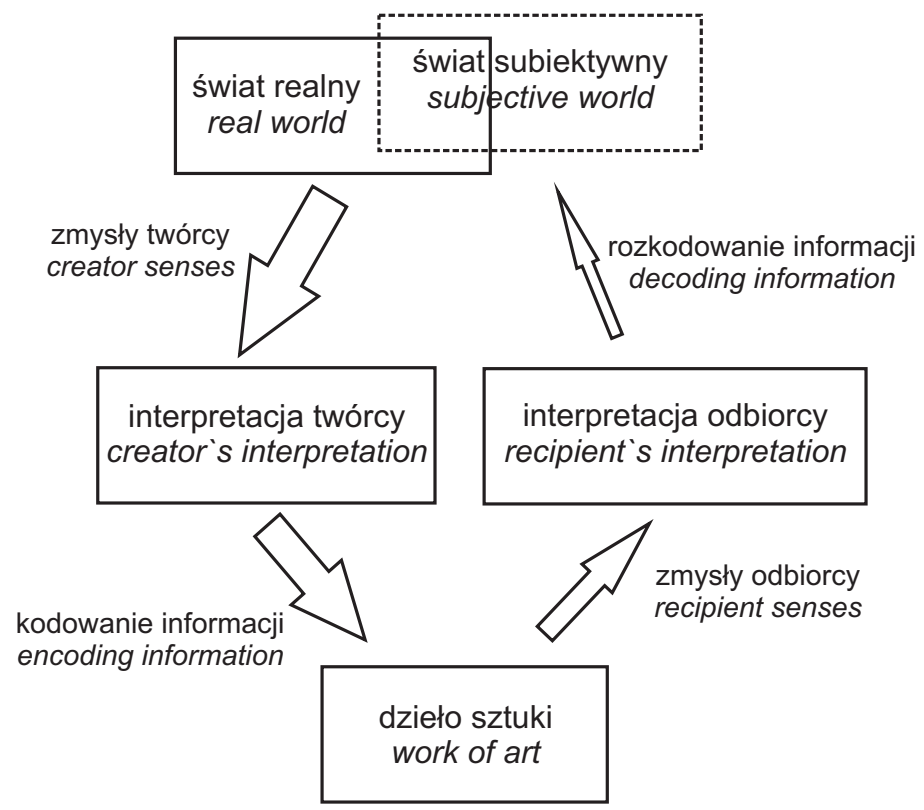

Ryc. 1. Model przekazu informacji za pomocą dzieła sztuki Opracowanie własne.

Model of communication message via a piece of art Author's own elaboration.

Warto w tym miejscu nawiązać do koncepcji komunikacji kartograficznej A. Robinsona i B. Petchenik (1975) i podzielić dzieło sztuki na kilka warstw informacyjnych (ryc. 2). Najważniejsza jest warstwa poznawcza (L1), dzięki której odbiorca zdobywa nową wiedzę o środowisku przyrodniczym lub społecznoekonomicznym. Warstwa informacji posiadanej (L2) ma dla odbiorcy mniejszą wartość, jednakże może ona potwierdzać dotychczas zdobytą wiedzę. Warstwa 
informacji obcej odbiorcy (L3) wykracza poza możliwości jego percepcji zmysłowej i intelektualnej, warstwa koncepcyjna (L4) zaś nie zawiera informacji płynących bezpośrednio z działa sztuki, lecz jest konsekwencją jego analizy. Jest to swoista „wiedza dodana” wynikającą z umiejętności kojarzenia faktów i zjawisk, których dzieło dotyczy.

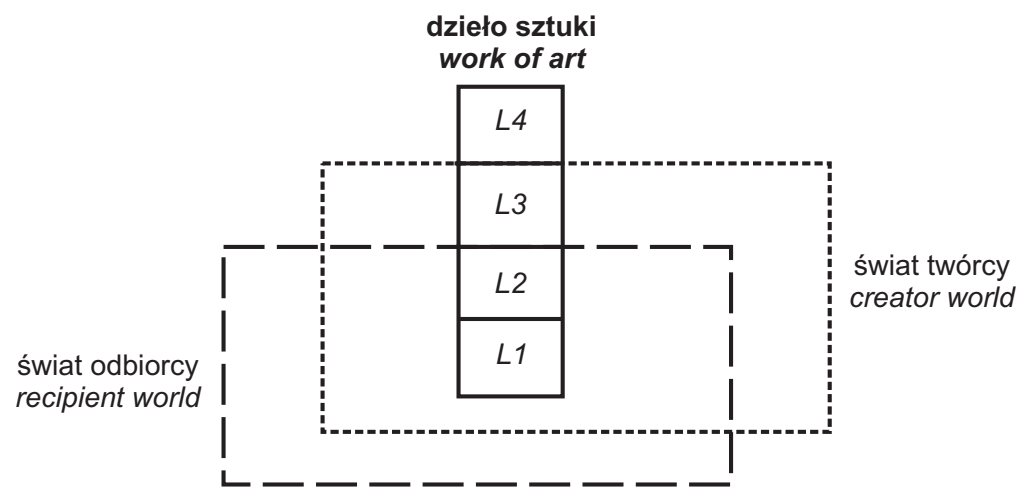

Ryc. 2. Warstwy informacyjne dzieła sztuki:

L1 - poznawcza, L2 - informacji posiadanej,

L3 - informacji obcej dla odbiorcy, L4 - koncepcyjna.

Opracowanie własne

A piece of art's information strata

L1 - cognitive, L2 - possessed information,

L3 - alien information for a recipient, L4 - conceptual.

Author's own elaboration

W procesie wykorzystania działa sztuki jako źródła informacji naukowej dużą rolę odgrywają dodatkowe czynniki, takie jak: umiejętności interpretacji dzieła i wiedza ogólna odbiorcy, stan zmysłów, swobodny dostęp do dzieła i inne. Warto w tym miejscu wrócić do podstawowego celu, jakiemu ma służyć badane dzieło sztuki: zdobyciu nowych - lub potwierdzeniu posiadanych - informacji. Aby ten cel osiągnąć, badacz-odbiorca wybiera spośród dzieł tylko te, które mogą być mu przydatne. Dla geografa przydatne może być na przykład malarstwo realistyczne (J.F Millet, J. Malczewski), a zupełnie nieprzydatne malarstwo surrealistyczne (S. Dali, Z. Beksiński).

Wśród nauk geograficznych i im pokrewnych, problematyka przekazu informacji jest domeną kartografów (Ratajski, 1977; Robinson i Petchenik, 1975; Guelke, 1976; Taylor, 1983). Mapa jest bowiem formą przekazu informacji (tzw. przekazu kartograficznego) przygotowaną przez twórcę - kartografa. Podstawowa różnica pomiędzy przekazem kartograficznym a przekazem potencjalnych informacji za pomocą dzieła sztuki polega na tym, że ten pierwszy jest bardziej 
sformalizowany i „uzgodniony” z odbiorcą. Mapa jest modelem rzeczywistości określonym na uzgodnionych i powszechnie przyjętych zasadach matematycznych i graficznych. W przypadku dzieła sztuki dopuszcza się dużą dowolność interpretacyjną i równie dużą dowolność technik przekazu (graficznych, muzycznych, literackich). Ale granice pomiędzy mapą a dziełem sztuki nie są ostre. Na przykład stare mapy wykonane w sposób „artystyczny” (z elementami dekoracyjnymi) są obecnie nie tylko źródłem informacji o poglądach i wiedzy ówczesnych geografów; traktuje się je także jako dzieła sztuki, które zdobią mieszkania i biura. Nawet współczesną mapę można wykorzystać jako motyw do tworzenia instalacji artystycznych (Storr, 1994).

\section{Dziedziny sztuki „użyteczne” w badaniach geograficznych}

W klasycznym podziale sztuki na dziedziny wymienia się na ogół: literaturę piękną, muzykę, taniec, teatr i film oraz sztuki plastyczne. Dziedziny te można dzielić dalej na grupy i podgrupy. I tak na przykład wśród sztuk plastycznych znajdą się: malarstwo, rzeźba, fotografika, grafika, scenografia, rysunek, instalacja i inne.

Nie wszystkie dziedziny sztuki mogą dostarczać dzieł artystycznych będących potencjalnym źródłem informacji dla geografa. Próżno by szukać tej cechy w muzyce, tańcu lub teatrze (w tym poza klasycznym teatrem, wymienia się balet, operę, „performance”). Co prawda znawca muzyki etnicznej lub różnych form tańca jest w stanie określić kraj lub region ich pochodzenia, ale nie ma to związku z „wydobywaniem” nowych elementów wiedzy o środowisku geograficznym (przyrodniczym i społeczno-ekonomicznym). Można podać wykorzystania muzyki w badaniach migracji kulturowych, ale mają one przede wszystkim charakter edukacyjny (Berry, 1988; Brouillette i Feder, 2010). Znając regiony powstania różnorodnych rytmów muzycznych, takich jak rap, rock, blues, gospel czy jazz (np. Missisipi, Nowy Orlean) wywodzących się z Afryki, możliwa jest analiza kierunków ich rozprzestrzeniania się.

Sam dźwięk i muzyka (szeroko rozumiana) dostarczają za pośrednictwem zmysłu słuchu wielu interesujących informacji geograficznych. Mówi się wręcz o krajobrazie dźwiękowym lub środowisku akustycznym (Bernat, 2002; Carles, Barcino i Lucio, 1999; Pocock, 1989; Waterman, 2000). Jednakże utwory muzyczne tworzone przez artystów są raczej pozbawione takiej informacji. Interpretowanie dźwięków i tworzenie na ich podstawie obrazu rzeczywistości byłoby poważnym nadużyciem ze względu na nadmierny subiektywizm.

W badaniach geograficznych bardziej użyteczna niż muzyka wydaje się być literatura piękna, czyli tekst o dominującej funkcji estetycznej języka. Odnajdziemy w niej niejednokrotnie tematykę odnoszącą się bezpośrednio do środowiska przyrodniczego lub przestrzeni, w której żyje i działa człowiek. Wyłączamy z naszego obszaru zainteresowań wszystkie teksty użytkowe o charak- 
terze informacyjnym, publicystycznym i naukowym, które nie mają wymiaru artystycznego. Istnieją w literaturze gatunki pograniczne, które trudno jednoznacznie przypisać do literatury pięknej lub użytkowej, ale są to już wyróżnienia wchodzące zbyt głęboko w kompetencje nauk o literaturze, niemające większego znaczenia w kwestiach podejmowanych w tym artykule.

Literatura piękna dostarcza nie tylko informacji geograficznych, ale również bardziej złożonej wiedzy o strukturze społecznej, różnicach przestrzennych, cechach regionów i mniejszych obszarów. Przykładem prostej, ale unikalnej informacji jest III pieśn Iliady Homera, z której dowiadujemy się, że starożytni Grecy mieli wiedzę geograficzną o równikowej Afryce i o ludach tego regionu. Homer pisze bowiem o Pigmejach, którzy zamieszkują trudno dostępną część centralnej Afryki. Ojciec historii Herodot także wspomina o karłowatym szczepie napotykanym przez Nassamonów.

„Gdy się uszykowały z wodzami orszaki,

Trojanie postępują z wrzawą jako ptaki;

Tak powietrze w niesfornej przebiegają wrzawie,

Uciekając przed zimą i słotą żurawie,

Wzbiwszy się pierzchliwymi skrzydły pod niebiosy;

Mija ocean, ciągnie z brzmiącymi odgłosy,

Śmierć i strach niosąc lotna Pigmejom gromada,

Którym wydaje bitwy, gdy z chmur na nie spada". ${ }^{1}$

Wiedza o Pigmejach może opierać się na źródłach egipskich. Już około 2500 lat p.n.e. Egipt organizował wyprawy na południe wzdłuż Nilu, mające na celu odnalezienie jego źródeł. Podróżnicy mogli wówczas zetknąć się z mieszkańcami centralnej Afryki. Boje Pigmejów z żurawiami są fantazją Homera, ale kierunek lotu żurawi w górę Nilu do obszarów zamieszkałych przez te ludy jest faktem. Poemat Homera był ważnym źródłem wiedzy dla H. Schliemanna - odkrywcy mitycznej Troi. Opisy poczynione przez Homera pozwoliły mu na odkrycie nie tylko „legendarnej” Troi (położonej dziś w Turcji), ale również wielu achajskich zabytków w Grecji. Iliada jest zatem przykładem dzieła literackiego, które stanowi źródło wiedzy między innymi w badaniach historycznych, archeologicznych i geograficznych.

W odniesieniu do geografii literatura piękna dostarcza też bardziej złożonych informacji. Istnieje wiele przykładów użycia języka literackiego do syntetycznego opisu zjawisk i procesów społeczno-ekonomicznych i przyrodniczych, takjak w prozie A. Stasiuka ${ }^{2}$ : ...,Jesienią widać, że to miasto umrze. Ci, co mieli wyjechać, dawno wyjechali.....Cztery skrzyżowania, jedno rondo, sygnalizacja miga na żółto już od dziesiątej. ...Żyje tylko stacja benzynowa. Nikt nie tankuje. Wszyscy kupują alkohol albo przesiadują w knajpie...". Taki opis jest kwintesencją diagnozy społeczno-gospodarczej peryferyjnego miasteczka, dotkniętego

\footnotetext{
${ }^{1}$ Pieśń III Iliady Homera (przekład F. Dmochowski), Zielona Sowa, Kraków, 2002.

${ }^{2}$ A. Stasiuk, 2009, Taksim, Wydawnictwo Czarne, Wołowiec, s. 6.
} 
problemem wyludniania i wykluczenia społecznego. Artysta będący bacznym obserwatorem życia codziennego, potrafi bez konieczności analizy materiałów statystycznych wychwycić i przedstawić w kilku zdaniach specyfikę i charakter lokalności, o której naukowiec rozpisywałby się na wielu stronach.

Klasycznym przykładem syntezy krajobrazu wiejskiego i gospodarstwa rolnego jest fragment księgi 1 Pana Tadeusza. Mickiewicz w kilku wierszach tekstu zawarł opis krajobrazu rolniczego położonego nad Niemnem, który tworzy u odbiorcy subiektywny obraz tego obszaru, ale także dostarcza mu konkretnych informacji o uprawach roślinnych i formie pól uprawnych. O wyglądzie gospodarstwa rolnego i jego specjalizacji wiele dowiadujemy się z następującego fragmentu księgi.

„Do tych pagórków leśnych, do tych łąk zielonych,

Szeroko nad błękitnym Niemnem rozciągnionych;

Do tych pól malowanych zbożem rozmaitem,

Wyzłacanych pszenicą, posrebrzanych żytem;

Gdzie bursztynowy świerzop, gryka jak śnieg biała,

Gdzie panieńskim rumieńcem dzięcielina pała,

A wszystko przepasane jakby wstęgą, miedzą

Zieloną, na niej z rzadka ciche grusze siedzą."

(...)

„Dom mieszkalny niewielki, lecz zewsząd chędogi,

I stodołę miał wielką, i przy niej trzy stogi

Użątku, co pod strzechą zmieścić się nie może;

Widać, że okolica obfita we zboże,

I widać z liczby kopic, co wzdłuż i wszerz smugów

Świecą gęsto jak gwiazdy, widać z liczby pługów

Orzących wcześnie łany ogromne ugoru,

Czarnoziemne, zapewne należne do dworu,

Uprawne dobrze na kształt ogrodowych grządek."

Jeszcze większą rolę poznawczą w geografii niż literatura piękna ma film, w tym szczególnie dzieła o charakterze oświatowym i dokumentalnym. Wymienione typy filmu w samym swoim założeniu niosą treści ważne dla nauki. Oprócz wartości edukacyjnej i poznawczej, dokumentują one stan przestrzeni geograficznej oraz służą wymianie myśli i poglądów na temat zjawisk i procesów badanych przez różne dyscypliny geografii. Ale film dokumentalny i edukacyjny w swojej treści przestaje być sztuką - jest bardziej dziełem naukowym prezentującym osiągnięcia nauki i poglądy indywidualnych badaczy lub ich zespołów przelane na różne formy ruchomego obrazu. W większości przypadków film dokumentalny jest zatem pewną formą wyrazu nauki. Treść filmu nie jest fik-

\footnotetext{
${ }^{3}$ A. Mickiewicz, 1950, Pan Tadeusz, Książka i Wiedza, Warszawa, s. 15.
} 
cją, lecz dokumentacją rzeczywistości, sztuką zaś pozostaje narracja, reżyseria, scenografia i montaż. Faza interpretacji rzeczywistości przez twórcę (patrz ryc. 1) wydaje się w tym przypadku pominięta lub nie w pełni wykształcona, bo ogranicza się do wyboru fragmentów rzeczywistości (dokumentów) a nie interpretacji sensu stricto. W przeciwieństwie do tego film fabularny jest dziełem artystycznym ze wszystkimi fazami modelu przekazu informacji - jest źródłem informacji faktograficznej (wynikającej bezpośrednio z obrazu zawartego na nośniku filmowym) oraz bardziej złożonej wiedzy wynikającej z samej treści filmu. Szczególną wartość mają filmy archiwalne, które mogą służyć analizom i porównaniom stanu przestrzeni geograficznej w okresie ostatnich 100 lat $^{4}$.

Wśród klasycznych dziedzin sztuki na uwagę geografa zasługuje malarstwo, które za pośrednictwem obrazu może dostarczać przede wszystkim wiedzy faktograficznej przydatnej w badaniach geograficznych. Dzieła dawnych mistrzów mogą nieść informacje o strukturze przestrzennej miast, układzie osad wiejskich, formach roślinności, kształcie i przebiegu koryt rzecznych, itp. Treść obrazu dostarcza przede wszystkim faktów historycznych; jest formą zapisu fotograficznego przestrzeni geograficznej w przeszłości. Utrwalony na płótnie lub papierze dawny krajobraz, wygląd osady, zarys granicy pól i lasów itp., można porównywać ze współczesnością i wyciągać wnioski na temat trendów i zmienności zjawisk. Zgromadzenie wielu faktów umożliwia natomiast szersze spojrzenie na stosunki społeczne, metody działalności gospodarczej, problemy przystosowanie człowieka do warunków przyrodniczych itd. Podobnej wiedzy mogą dostarczać inne formy dzieł plastycznych, na przykład miedzioryty i drzeworyty, aczkolwiek prezentowany przez nie obraz rzeczywistości jest bardziej schematyczny i symboliczny.

\section{Malarstwo i wiedza geograficzna - wybrane przykłady}

Malarstwo posługuje się środkami plastycznego wyrazu umieszczonymi na ogół na płaskiej powierzchni. Istnieją dziesiątki technik i stylów malarskich, a niektóre z nich wykluczają możliwość wykorzystania dzieła do badań geograficznych. Równie bogate jest spektrum tematyki malarskiej, wśród której najistotniejsze dla geografa jest malarstwo pejzażowe i rodzajowe. To pierwsze przedstawia krajobraz i naturę, drugie - tematykę związaną z życiem codziennym. W malarstwie pejzażowym wyróżnia się nawet pejzaż topograficzny, który przedstawia konkretną-- niebędącą wytworem wyobraźni - rzeczywistość.

Kombinacja malarstwa krajobrazowego i rodzajowego jest obraz Żniwiarze (Pieter de Elder, Bruegel, 1565). Dowiadujemy się z niego o ówczesnym krajobrazie wiejskim, formach zagospodarowania przestrzeni, układzie pól upraw-

\footnotetext{
${ }^{4}$ Pierwsze filmy, na przykład Wyjście robotników z fabryki Lumiere w Lyonie i Wjazd pociagu na stację La Ciota z 1895 r. miały wyłącznie charakter dokumentalny. Za pierwszy film fabularny (inscenizowany) uznaje się Oblanego ogrodnika (Ogrodnik i żartowniś) braci Lumiere z tego samego roku.
} 
nych i dróg dojazdowych oraz metodach prac polowych (ryc. 3). Poza czysto faktograficzną informacją możemy wyciągać wnioski na temat społecznego podziału pracy na wsi, form współpracy oraz codziennych obowiązków w okresie żniw. Studia innych dzieł o tematyce wiejskiej tego artysty (np. Wiosna 1569, Lato 1569, Letni krajobraz 1569) dostarczają bardzo cennej wiedzy historykom, antropologom kultury, etnografom i geografom. Dla geografa interesujące są przede wszystkim formy krajobrazu wiejskiego, lokalizacja osad i rozmieszczenie gospodarstw domowych, funkcje wsi, struktura użytkowania ziemi i zagospodarowanie przestrzenne.

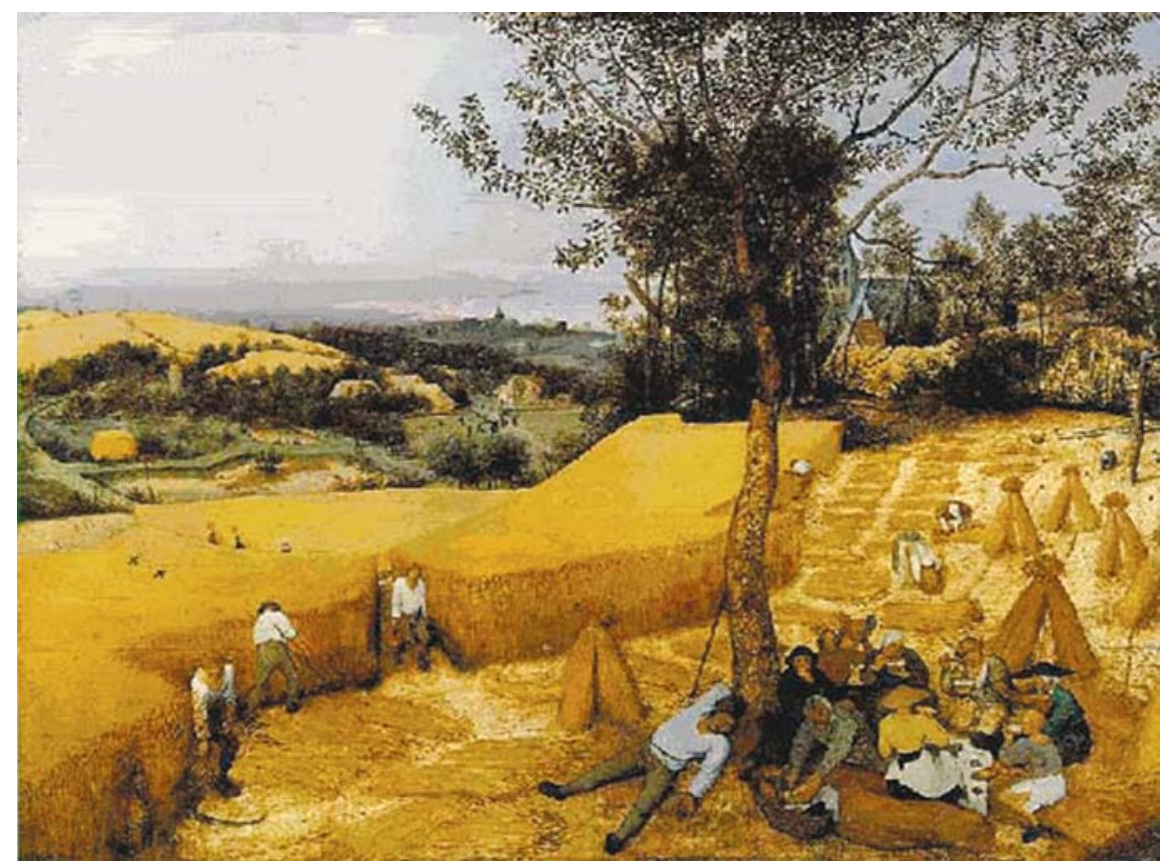

Ryc. 3. Żniwiarze, Pieter de Elder, Bruegel, 1565

Harvesters, Pieter de Elder, Bruegel, 1565

Dobrym przykładem malarstwa krajobrazowego jest obraz Philipa Dombecka pt. Wjazd gen. Zajączka do Lublina w 1826 r., przedstawiający architekturę i założenia urbanistyczne ówczesnego Lublina (ryc. 4). Na pierwszym planie widoczny jest trakt zamojski, a dalej zabudowa staromiejska i w głębi zamek. Obraz może stanowić podstawę do głębszych studiów z zakresu urbanistyki i zagospodarowania przestrzennego miasta i jego sąsiedztwa. W przeszłości wykonano szereg malowideł i rycin przedstawiających panoramę Lublina, które były tematem wystawy w Muzeum Lubelskim pt. Portret miasta. Lublin 
w malarstwie, grafice i rysunku 1618-1939 (Bartnik, 2009). Dzięki temu studia zagospodarowania przestrzennego miasta i obszarów podmiejskich mogą być wzbogacone o porównania i analizę zmian w różnych przekrojach czasowych.

Wiele interesujących informacji przydatnych dla geografa zawierają rysunki J. Ceglińskiego i A. Matuszkiewicza zebrane w Albumie widoków i okolic Warszawy ${ }^{5}$ (ryc. 5). Rysunki przedstawiają m.in. Wisłę jako element przestrzeni społeczno-ekonomicznej miasta. Wynika z nich, że rzeka była wówczas ważnym szlakiem komunikacyjnym i pełniła również inne funkcje gospodarcze. Współcześnie Warszawa jest „odwrócona plecami” do Wisły.

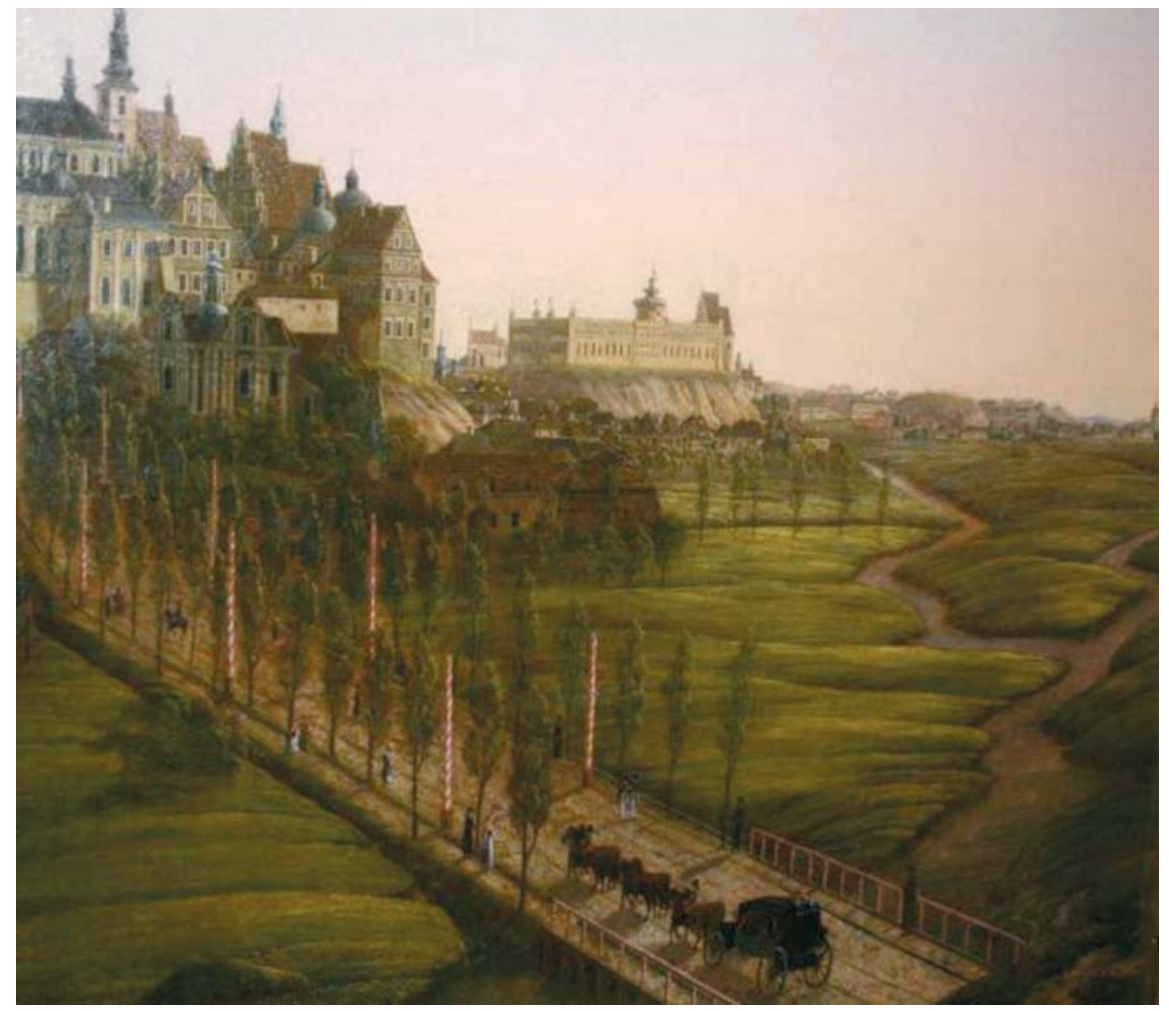

Ryc. 3. Wjazd gen. Zajaczka do Lublina w 1826 r., P. Dombeck, 1926 General Zajaczek's entry into the city of Lublin in 1826, P. Dombeck, 1926

Przykładem malarstwa rodzajowego może być akwarela Stanisława Masłowskiego z 1989 r., zatytułowana Na pastwisku (ryc. 6). Dostarcza ona przede

\footnotetext{
${ }^{5}$ J. Cegliński, A. Matuszkiewicz, 1855, Album widoków i okolic Warszawy, A. Pecq, Warszawa (Biblioteka Narodowa).
} 


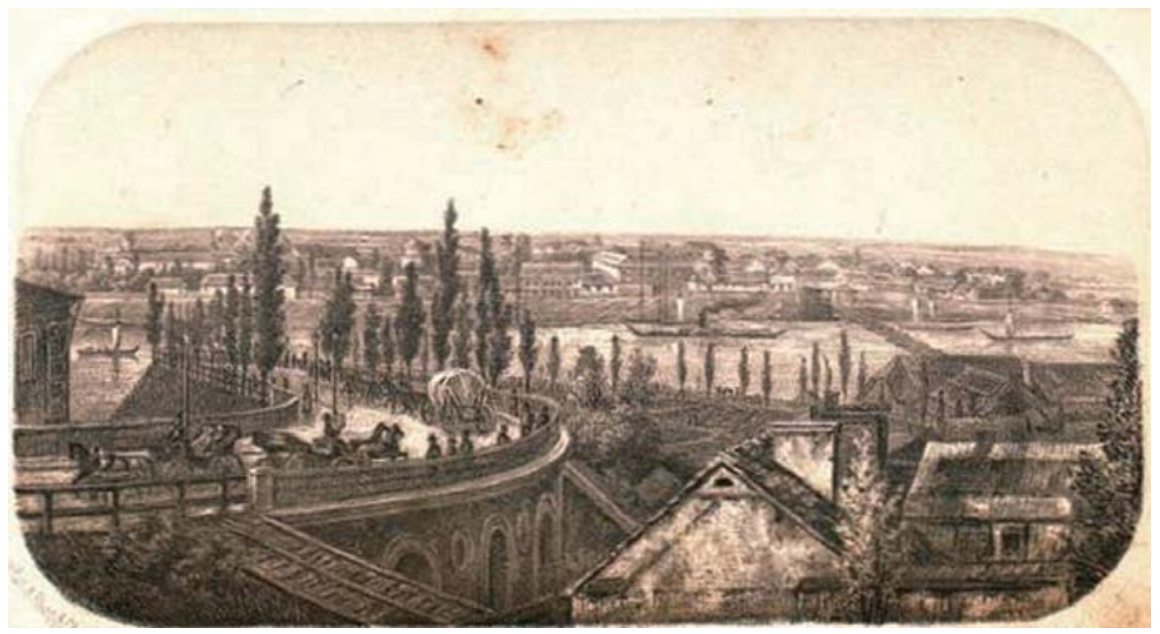

Ryc. 4. Rycina z Albumu widoków i okolic Warszawy (zob. przypis 5)

Drawing from the Album of views of Warsaw and its neighbourhood areas

wszystkim informacji historycznej, która może być także wykorzystana w geografii wsi i rolnictwa. Dowiadujemy się z niej między innymi o formie wypasu bydła na obszarach nizinnych na przełomie XIX i XX wieku, liczebności stada i jego zróżnicowaniu rasowym (dostrzec można rasę czerwono-białą, czarnobiałą, polską czerwoną. Stado doglądane przez pasterza ma pełną swobodę.

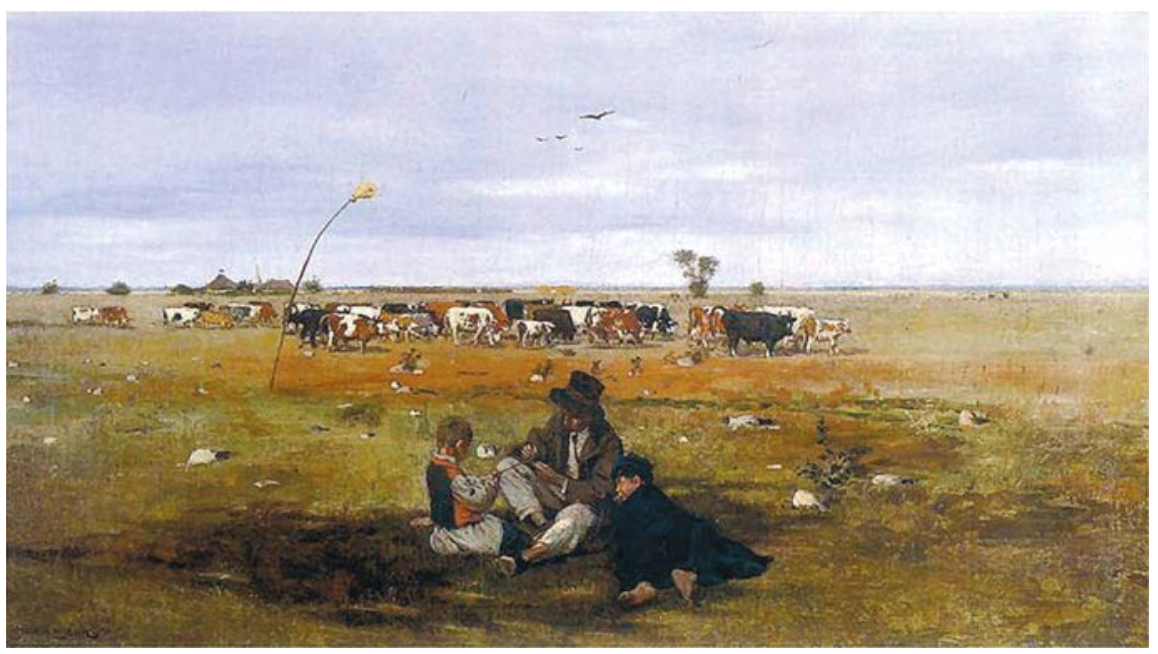

Ryc. 6. Na pastwisku, S. Masłowski, 1889

On the pasture, S. Masłowski, 1889 
Pastwisko ma charakter naturalny, znajduje się prawdopodobnie na niskiej jakości glebach i przypomina współczesne nieużytki.

Analiza innych dzieł z tego okresu o podobnej tematyce, tj. przedstawiających sceny pasterskie (T. Axentowicz - Gęsiarka, J. Brandt - Na pastwisku, A. Kędzierski - W polu, R. Kochanowski - Gąski, J. Szermentowski - Bydło na pastwisku) dostarcza informacji o wyglądzie i zróżnicowaniu gatunkowym wypasanych zwierząt, miejscach i formie wypasu. Oprócz uzyskania konkretnych informacji faktograficznych można też podjąć próby bardziej ogólnych interpretacji dotyczących roli pasterstwa w ówczesnym rolnictwie w Polsce.

Godnym uwagi przykładem dzieła plastycznego będącego źródłem informacji o polskiej wsi XVII wieku jest drzeworyt Wizerunek stugi wiernego (ryc. 7). Dzieło przedstawia codzienne życie i stosunki społeczne na siedemnastowiecznej polskiej wsi. Dowiadujemy się z niego m.in. o narzędziach rolniczych i zwierzętach hodowlanych oraz o rodzajach pracy na wsi. Z drzeworytu wynika, że w ówczesnej Polsce rozwinięta była uprawa winogron, z których produkowano wina. Wśród zwierząt hodowlanych główną rolę odgrywało bydło, konie i owce

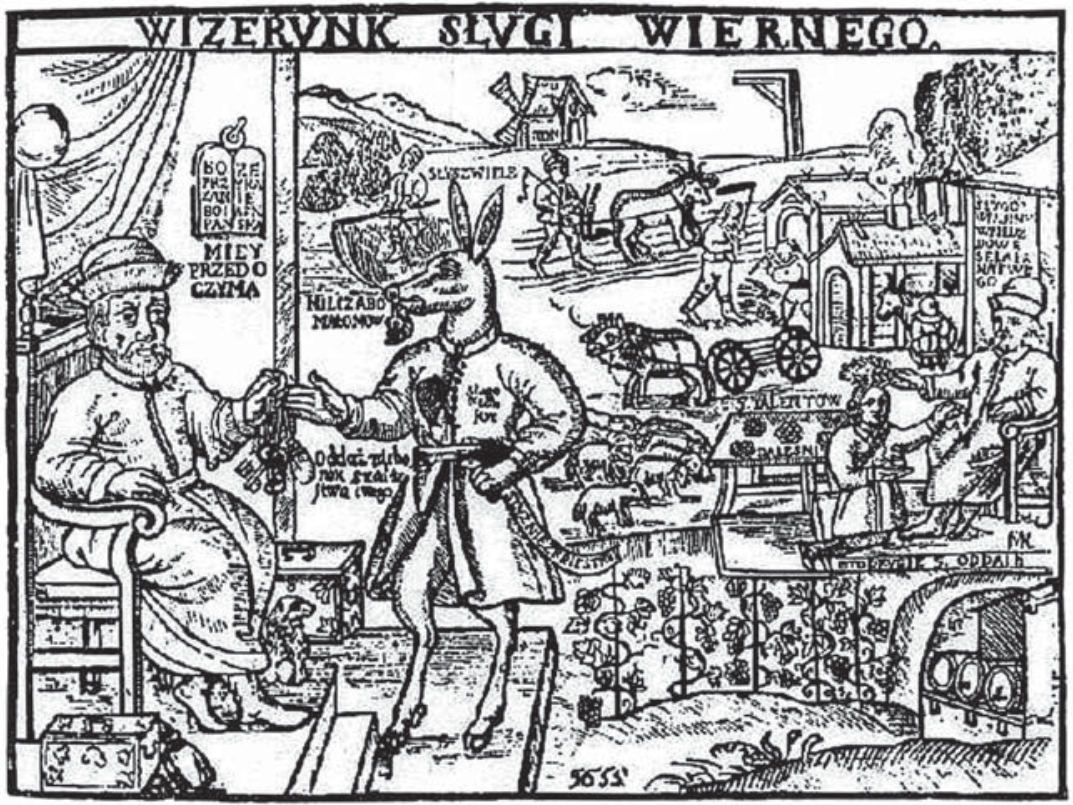

Ryc. 7. Wizerunek stugi wiernego, drzeworyt przedstawiający różne czynności w folwarku z XVII w. ${ }^{6}$

Image of the loyal servant, woodcut presenting various activities on a manor farm in the 17 th century 6

${ }^{6}$ T. Seweryn, 1956, Staropolska grafika ludowa, Wydawnictwo Sztuka, Warszawa. 
(znaczenie trzody chlewnej wzrosło dopiero w końcu XIX w., dlatego na ogół nie pojawia się ona na wcześniejszych pracach).

Jak wykazano wcześniej, odbiór i interpretacja działa sztuki jest bardzo subiektywnym procesem. Różni odbiorcy mogą z tego samego dzieła uzyskać różne informacje szczegółowe, ale w warstwie ogólnej wnioski powinny być podobne. Innymi słowy, aby wiedza płynąca z dzieła sztuki miała dla geografa charakter poznawczy, grupa odbiorców powinna wyciągać z niego podobne wnioski. Tezę taką potwierdziły badania wykonane wśród 13 studentów geografii (III i V rok studiów). Studenci zapoznali się z 18 polskimi obrazami olejnymi i akwarelami ilustrującymi wieś i codzienne życie na wsi z przełomu XIX i XX wieku. Następnie poproszono ich o omówienie potencjalnych informacji geograficznych wynikających z treści dzieł. W odpowiedziach znalazły się przede wszystkim fakty dostrzegane na obrazach. Na przykład treść obrazu S. Masłowskiego Na pastwisku charakteryzowana była w postaci takich opisów jak: „duże stado krów”, „pastwisko na nieurodzajnej ziemi”, „bydło różnych ras” i „hodowla bydła”. Zdarzały się jednak wnioski (nie zawsze uzasadnione) mające charakter poznawczy, np. „ubogie gleby zmuszały do hodowli zwierząt, bo uprawa roślin była nieopłacalna”, „słabe gleby uniemożliwiały produkcję roślinną, dlatego wykorzystane były pod pastwiska".

Kilku studentów na podstawie analizy całego zbioru dzieł plastycznych wyciągnęło szersze wnioski dotyczące form hodowli zwierząt i ich gatunków, stosowania narzędzi rolniczych, podziału pracy w gospodarstwie rolnym oraz struktury przestrzennej osad wiejskich. Oto fragment opisu wykonanego przez jednego ze studentów: „... (mieszkańcy wsi - przyp. JB) Są tak jakby nieodłączną częścią świata, w którym żyją i który w jakiś sposób tworzą. ... Wszystko tutaj do siebie pasuje .... ludzie żyją w zgodzie ze sobą, to natura wyznacza im cykl życia i pracy i oni się z tym zgadzają”. Inny student napisał: „... w tych obrazach widzę przede wszystkim bardzo silny związek człowieka z przyrodą .... Przyroda wyznacza tym ludziom cykl życia”.

\section{Wnioski}

Geografia jako nauka empiryczna ma bardzo ograniczone relacje ze sztuką. Tylko w przypadku geografii kultury i historii geografii podejmowane są nieśmiałe próby włączenia różnych dziedzin sztuki w zakres ich tematyki badawczej. Badane są regionalne różnice kulturowe pod względem działalności artystycznej, wpływ lokalizacji przestrzennej na zróżnicowanie nurtów w sztuce, możliwości edukacji geograficznej poprzez sztukę. Najwięcej tego typu badań prowadzi się w Stanach Zjednoczonych.

Dzieło sztuki może być źródłem wiedzy w badaniach geograficznych. Jednakże musi spełniać kilka podstawowych warunków. Jego tematyka powinna odnosić się do świata realnego - dzieło jest wówczas formą obrazu rzeczywisto- 
ści stworzonego przez artystę. Świat subiektywny powstały u odbiorcy w całym procesie przekazu informacji musi mieć „części wspólne” ze światem realnym. W przeciwnym wypadku wyciągnięte wnioski będą na ogół błędne. Ważnym elementem poznania rzeczywistości za pośrednictwem dzieła sztuki jest poziom wykształcenia i „wyrobienie” artystyczne odbiorcy.

Wśród różnych rodzajów dzieł sztuki, szczególną rolę w badaniach geograficznych mogą odgrywać dzieła plastyczne (głównie malarstwo), literatura piękna oraz film. Mają one na ogół charakter dokumentacyjny, tj. przedstawiają fragment przestrzeni geograficznej w przeszłości historycznej. Analiza dzieł sztuki nie tylko dostarcza wiedzy faktograficznej, ale także czyni możliwym wyciąganie wniosków na temat stosunków społecznych, form zagospodarowania przestrzeni i ich zmienności, funkcji społeczno-gospodarczych wybranych obszarów itp.

Problematyka możliwości wykorzystania dzieła sztuki w badaniach geograficznych należy do zagadnień „niszowych” - w polskiej geografii nie prowadzi się tego typu badań. W niektórych przypadkach dzieło sztuki może być jedynym źródłem informacji geograficznej, dlatego warto zachęcić geografów do podejmowania tej tematyki.

\section{Piśmiennictwo}

Bartnik R., 2009, Portret miasta. Lublin w malarstwie, rysunku i grafice 1618-1939, Muzeum Lubelskie, Lublin.

Bernat S., 2002, Geografia a dźwięk i muzyka, [w:] E. Orłowska (red.), Kultura jako przedmiot badań geograficznych, PTG, Uniwersytet Wrocławski, Wrocław, t. II, s. 55-64.

Berry J., 1988, African cultural memory in New Orleans music, Black Music Research Journal, 8, s. 3-12.

Brouillette L., Feder S., 2010, Tracing Cultural Migration trough Music: An Inquiry Approach to Enhancing Global Understanding, Ohio Social Studies Review

http://www.clta.uci.edu/Tracing_Cultural_Migration_through_Music_Brouillette\& Feder.pdf (luty 2011).

Carles J.L., Barrino I.L., de Lucio J.V., 1999, Sound influence on landscape values, Landscape and Urban Planning, 43, 4, s. 191-200.

Carney G.O., 1998, Music geography, Journal of Cultural Geography, 18, s. 455-464.

Childs I.R.W., 1991, Japanese perception of nature in the Novel Snow Country, Journal of Cultural Geography, 11, 2, s. 1-19.

Crouch D, Toogood M., 1999, Everyday abstraction: geographical knowledge in the art of Peter Lanyon, Cultural Geographies, 6, 1, s. 72-89.

Fiona A., Mackenzie D., 2006, Against the tide: placing visual art in the Highlands and Islands, Scotland, Social and Cultural Geography, 7, 6, s. 965-985.

Guelke L., 1976, Cartographic communication and geographic understanding, The Canadian Cartographer, 13, 2, s. 107-122.

Holzer J., 1978, Świat zdeformowany. Dzieło literatury XX wieku jako źródto historyczne, [w:] Z. Stefanowska, J. Sławiński (red.), Dzieło literackie jako źródto historyczne, Czytelnik, Warszawa, s. 336. 
Hawkins H., 2010, Turn your trash into... Rubbish, art and politics. Richard Wentworth's geographical imagination, Social and Cultural Geography, 11, 8, s. 805-827.

Ingarden R., 1970, Przeżycie estetyczne, [w:] Dzieła filozoficzne. Studia z estetyki, t. 3, PWN, Warszawa, s. 97-102.

Jeffus S., Aramini J., 2008, Geography Through Art, Geography Matters, Nancy, KY.

Karan P.P., 1984, Landscape, religion and folk art in Mithila: An Indian cultural region, Journal of Cultural Geography, 5, 1, s. 85-101.

Kaufmann T., 2004, Toward a Geography of Art, University of Chicago Press, Chicago.

Lukinbeal Ch., 2005, Cinematic landscapes, Journal of Cultural Geography, 23, 1, s. 3-22.

Maternicki J., 1963, Literatura piękna w nauczaniu historii, PWN, Warszawa.

Morris E., 2005, The cultural geographies of Abstract Expressionism: painters, critics, dealers and the production of an Atlantic art, Social and Cultural Geography, 6, 3, s. 421-437.

Nash P.H., 1968, Music regions and regional music, The Deccan Geographer, 6, s. 1-24.

Olwig K., 1987, Art and the art of communicating geographical knowledge: the case of Pieter Brueghel, Journal of Geography, 86, 2, s. 47-51.

Orłowska E. (red.), 2002, Kultura jako przedmiot badań geograficznych, t. 1 i 2, PTG, Uniwersytet Wrocławski, Wrocław.

Orneta A. G., Valdes C. M., 2007, Cinema and geography: Geographic space, landscape and territory in the film industry, Boletin de la Asociacion de Geografos Españoles, 45, S. 407-410.

Pocock D.C., 1989, Sound and the geographer, Geography, 74, s. 193-200.

Radomski A., 2001, Sztuka jako źródto do badania historii. Czy historiografia jest sztuka (na przykładzie literatury)?, Kultura i Historia, 1, UMCS, Lublin, s. 86-98.

Ratajski L., 1977, Straty $i$ zyski informacji w przekazie kartograficznym, Polski Przegląd Kartograficzny, 9, 3, s. 97-104.

Robinson A.H., Pechenik B.B., 1975, The map as communication system, The Cartographic Journal, 12, s. 7-15.

Seemann J. 2009, Art, geographical knowledge and image reading: Vermeer's "Geographer", Pro-Posições, 20, 3, s. 43-60.

Storr R., 1994, Mapping, The Museum of Modern Art, New York.

Taylor D.R. (red.), 1983, Progress in Contemporary Cartography. Graphic Communication and Design in Contemporary Cartography, 2, John Wiley, New York.

Topolski J., 1978, Korzystanie ze źródet literackich w badaniach historycznych, [w:] Z. Stefanowska, J. Sławiński (red.), Dzieło literackie jako źródto historyczne, Czytelnik, Warszawa, s. 7-30.

Waterman E., 2000, Sound escape: sonic geography remembered and imagined, Cultural Geographies, 7, 1, s. 112-115.

[Wpłynęło: styczeń; poprawiono: marzec 2011 r.] 


\section{JERZY BAŃSKI}

\section{WORK OF ART AS A SOURCE IN GEOGRAPHICAL RESEARCH}

The aim of the paper is to evaluate the possibilities for using a classical piece of art, on the example of literature (belle-lettres) and painting, as a source of knowledge in geographical studies, as well as preparing a communication message model with the use of a work of art. As an empirical science, geography maintains a very limited relations with arts. Only as regards the cultural and historical geography, there are timid attempts here and there to include various breeds of arts for scientific purposes. Among issues subject to investigation are: regional cultural differences in respect of artistic creation, effects of spatial location on diversification of trends in arts and the educational potential of arts. These types of research are particularly popular in the United States.

A piece of art can be a source of knowledge in geographical studies. However, it must fulfill several basic conditions. Its subject matter should relate to the real world. A given work of art constitutes then an artistic expression of reality. The subjective world created in the mind of a recipient (viewer or reader) in the process of conveying the message needs to share the common factors with the real world. Otherwise the conclusions arrived at can be generally false. A level of education and a kind of sophistication constitute a key element in learning about the reality via the encounter with a piece of art.

Among various forms of arts, as regards the geographical studies, plastic arts (especially, painting), literature (belles-lettres) and film play a particular role. This is so, overall, due to their intrinsic documentary character, i.e., they depict a portion of geographical space in the historical past. An analysis of piece of art may provide not only factual knowledge, but also makes it possible to draw conclusions concerning social relationships, forms of spatial organization and their changeability, socio-economic functions of selected areas, etc.

The subject matter dealing with the use of a piece of art in geographical studies belongs to a "niche" area of study - in Polish geography these types of research is virtually non-existent. Since, in some cases, a work of art maybe an only source of knowledge, the geographers should be encouraged to take up that field of study. 